\title{
Article \\ Distinct Concentration-Dependent Molecular Pathways Regulate Bone Cell Responses to Cobalt and Chromium Exposure from Joint Replacement Prostheses
}

\author{
Karan M. Shah ${ }^{1} \mathbb{D}$, Mark J. Dunning ${ }^{2}$, Alison Gartland ${ }^{1, *}$ and J. Mark Wilkinson ${ }^{1, *(D)}$ \\ 1 The Mellanby Centre for Musculoskeletal Research, Department of Oncology and Metabolism, \\ The University of Sheffield, Beech Hill Rd, Sheffield S10 2RX, UK; k.shah@sheffield.ac.uk \\ 2 Sheffield Bioinformatics Core, The University of Sheffield, 385a Glossop Rd, Sheffield S10 2HQ, UK; \\ m.j.dunning@sheffield.ac.uk \\ * Correspondence: a.gartland@sheffield.ac.uk (A.G.); j.m.wilkinson@sheffield.ac.uk (J.M.W.); \\ Tel.: +44-(0)1-14-215-9046 (A.G.); +44-(0)1-14-215-9029 (J.M.W.); \\ Fax: +44-(0)1-14-271-2475 (A.G.); +44-(0)1-14-261-8775; (J.M.W.)
}

\section{check for} updates

Citation: Shah, K.M.; Dunning, M.J.; Gartland, A.; Wilkinson, J.M. Distinct Concentration-Dependent Molecular Pathways Regulate Bone Cell Responses to Cobalt and Chromium Exposure from Joint Replacement Prostheses. Int. J. Mol. Sci. 2021, 22, 5225. https://doi.org/10.3390/ ijms22105225

Academic Editor: Fredrick M. Pavalko

Received: 9 April 2021

Accepted: 8 May 2021

Published: 14 May 2021

Publisher's Note: MDPI stays neutral with regard to jurisdictional claims in published maps and institutional affiliations.

Copyright: (c) 2021 by the authors. Licensee MDPI, Basel, Switzerland. This article is an open access article distributed under the terms and conditions of the Creative Commons Attribution (CC BY) license (https:// creativecommons.org/licenses/by/ $4.0 /)$.

\begin{abstract}
Systemic cobalt (Co) and chromium (Cr) concentrations may be elevated in patients with metal joint replacement prostheses. Several studies have highlighted the detrimental effects of this exposure on bone cells in vitro, but the underlying mechanisms remain unclear. In this study, we use whole-genome microarrays to comprehensively assess gene expression in primary human osteoblasts, osteoclast precursors and mature resorbing osteoclasts following exposure to clinically relevant circulating versus local periprosthetic tissue concentrations of $\mathrm{Co}^{2+}$ and $\mathrm{Cr}^{3+}$ ions and $\mathrm{CoCr}$ nanoparticles. We also describe the gene expression response in osteoblasts on routinely used prosthesis surfaces in the presence of metal exposure. Our results suggest that systemic levels of metal exposure have no effect on osteoblasts, and primarily inhibit osteoclast differentiation and function via altering the focal adhesion and extracellular matrix interaction pathways. In contrast, periprosthetic levels of metal exposure inhibit both osteoblast and osteoclast activity by altering HIF- $1 \alpha$ signaling and endocytic/cytoskeletal genes respectively, as well as increasing inflammatory signaling with mechanistic implications for adverse reactions to metal debris. Furthermore, we identify gene clusters and KEGG pathways for which the expression correlates with increasing $\mathrm{Co}^{2+}: \mathrm{Cr}^{3+}$ concentrations, and has the potential to serve as early markers of metal toxicity. Finally, our study provides a molecular basis for the improved clinical outcomes for hydroxyapatite-coated prostheses that elicit a pro-survival osteogenic gene signature compared to grit-blasted and plasmasprayed titanium-coated surfaces in the presence of metal exposure.
\end{abstract}

Keywords: hip replacement; osteoblasts; osteoclasts; cobalt; chromium; gene expression; microarray; prosthesis surface

\section{Introduction}

The observed early failure rate for joint replacement prostheses that use a metal-onmetal (MoM) bearing have highlighted the adverse effects of cobalt $(\mathrm{Co})$ and chromium $(\mathrm{Cr})$ on tissue in the periprosthetic environment [1,2]. Tribocorrosion at the bearing surfaces of MoM prostheses, and at modular junctions of all hip prostheses, causes persistent elevation of Co and $\mathrm{Cr}$ levels both locally and systemically.

Clinically, we have reported that patients with MoM hip resurfacings and relatively higher circulating concentrations of $\mathrm{Co}$ and $\mathrm{Cr}$ (in the interquartile range 1 to $7 \mu \mathrm{g} / \mathrm{L}$ ) have reduced bone turnover systemically and increased total bone mineral density compared to individually matched patients with a conventional metal-on-polyethylene (MoP) bearing hip prostheses [3]. There is also extensive evidence that suggests detrimental effects of metal exposure on the survival and function of several cell types including monocytes, 
macrophages and bone cells in vitro [4-8]. However, the molecular mechanisms for these effects remain unclear.

A recent RNA-seq-based study compared synovial tissues from patients with adverse reaction to metal debris (ARMD) to those from patients with MoP and reported changes in genes associated with redox homeostasis and macrophage activation [9]. Another study that investigated the effects of $\mathrm{Co}$ and $\mathrm{Cr}$ exposure in osteoblast-like cells using an osteogenic gene-panel, at supra-physiological concentrations (250 $\mu \mathrm{M}: ~ 12,500 \mu \mathrm{g} / \mathrm{L})$, reported down-regulation of genes involved in TGF-beta signaling and collagen production [10]. While these studies increase our understanding of the effects metal exposure may have in the periprosthetic environment, they fail to provide a comprehensive transcriptomewide insight into the response of primary human osteoblasts and osteoclasts exposed to clinically equivalent systemic concentrations of metal exposure.

We have previously shown that routinely used topographical and chemical alteration of prosthetic surfaces alter the physiological response of osteoblast-like cells to clinically relevant levels of metal exposure [7]. We observed a smaller reduction in osteogenic activity of SaOS-2 cells following $\mathrm{Co}$ and $\mathrm{Cr}$ exposure when grown on hydroxyapatitecoated surfaces (HA) compared to those grown on grit-blasted (GB) or plasma-sprayed titanium-coated (Ti) surfaces, with implications for osseointegration of the prosthesis. The molecular mechanisms that mediate this relative protective effect also remains unknown.

In this study, we use whole-genome microarrays to assess differential gene expression in primary human osteoblasts and osteoclasts grown in vitro, and in osteoblasts grown on different prosthesis surfaces following exposure to clinically relevant concentrations of Co and $\mathrm{Cr}$.

\section{Results}

\subsection{Effect of Cobalt and Chromium Exposure on Primary Human Osteoblasts}

For osteoblasts grown in vitro on tissue culture plates and exposed to systemic concentrations of metal ions observed for well-functioning MOM prosthesis, $5 \mu \mathrm{g} / \mathrm{L} \mathrm{Co}^{2+}: \mathrm{Cr}^{3+}$ did not significantly alter gene expression compared to the untreated cells. In contrast, $500 \mu \mathrm{g} / \mathrm{L} \mathrm{Co}^{2+}: \mathrm{Cr}^{3+}$ (equivalent to the concentration of metal ions found periprosthetically for a well-functioning MOM prosthesis) up-regulated 25 genes (Table 1). KEGG pathway analyses identified overrepresentation of genes associated with the HIF-1 signaling pathway (KEGG:04066; $P=4.15 \times 10^{-7}$ ), fructose and mannose metabolism (KEGG:00051; $P=8.90 \times 10^{-4}$ ) and renal cell carcinoma (KEGG:05211; $P=3.345 \times 10^{-2}$ ) in the upregulated genes (Table 2). Specifically, in the HIF-1 signaling pathway, genes associated with anaerobic metabolism and reduction in oxygen consumption (PDK-1 and PFKFB3; $\log _{2} \mathrm{FC}$ of 2.04 and 1.59 and $P$ values of $1.1 \times 10^{-7}$ and $6.6 \times 10^{-4}$ respectively), and increase in oxygen delivery $\left(V E G F A, \log _{2} \mathrm{FC}=1.6\right.$ and $\left.P=3.8 \times 10^{-4}\right)$ were up-regulated. Other known HIF-1 targets such as ANKRD37 $\left(\log _{2} \mathrm{FC}=1.89\right.$ and $\left.P=3.6 \times 10^{-4}\right)$ and $B N I P 3\left(\log _{2} \mathrm{FC}=1.83\right.$ and $\left.P=1.4 \times 10^{-6}\right)$ were also up-regulated.

Gene probes that showed significant dose-dependent effects with increasing concentrations of $\mathrm{Co}^{2+}: \mathrm{Cr}^{3+}$ formed nine individual clusters (Figure 1, Supplementary Table S1). Functional classification of these gene clusters identified HIF-1 signalling $\left(P=5.2 \times 10^{-7}\right.$; Cluster 1$)$ and Glycolysis/Gluconeogenesis $\left(P=1.02 \times 10^{-6}\right.$; Cluster 2$)$ pathways that associated positively with increasing concentrations. Exposure to $\mathrm{CoCr}$ nanoparticles (100 nanoparticles of $\mathrm{Co}$ and $\mathrm{Cr}_{2} \mathrm{O}_{3}$ each per cell) did not alter the gene expression significantly. 
Table 1. Genes altered in osteoblasts following $24 \mathrm{~h}$ exposure to $500 \mu \mathrm{g} / \mathrm{L} \mathrm{Co}^{2+}: \mathrm{Cr}^{3+}$.

\begin{tabular}{ccc}
\hline Gene & Log $_{2}$ FC & $p$ Value \\
\hline PDK1 & 2.04 & $1.16 \times 10^{-7}$ \\
ANKRD37 & 1.89 & $3.63 \times 10^{-5}$ \\
APLN & 1.88 & $3.18 \times 10^{-5}$ \\
AK4 & 1.85 & $2.78 \times 10^{-4}$ \\
BNIP3 & 1.83 & $1.41 \times 10^{-6}$ \\
PFKFB3 & 1.69 & $6.57 \times 10^{-5}$ \\
VEGFA & 1.59 & $3.85 \times 10^{-4}$ \\
VLDLR & 1.59 & $8.95 \times 10^{-4}$ \\
SLC2A1 & 1.59 & $6.65 \times 10^{-4}$ \\
PFKFB4 & 1.59 & $2.32 \times 10^{-5}$ \\
LO101929947 & 1.51 & $6.00 \times 10^{-4}$ \\
TCAF2 & 1.47 & $3.20 \times 10^{-4}$ \\
ALDOC & 1.46 & $1.53 \times 10^{-4}$ \\
ENO2 & 1.42 & $2.98 \times 10^{-5}$ \\
INHBB & 1.41 & $1.89 \times 10^{-4}$ \\
FAM162A & 1.33 & $8.58 \times 10^{-6}$ \\
P4HA1 & 1.25 & $1.36 \times 10^{-4}$ \\
DDIT4 & 1.22 & $5.04 \times 10^{-4}$ \\
NXPH4 & 1.21 & $3.79 \times 10^{-4}$ \\
EGLN1 & 1.19 & $4.75 \times 10^{-5}$ \\
GYS1 & 1.17 & $4.17 \times 10^{-5}$ \\
BNIP3L & 1.16 & $9.58 \times 10^{-6}$ \\
PGK1 & 1.12 & $7.77 \times 10^{-5}$ \\
RORA & 1.10 & $8.68 \times 10^{-4}$ \\
PPP1R3C & 1.01 & $1.44 \times 10^{-4}$ \\
\hline & &
\end{tabular}

Table 2. Functional classification of genes altered in osteoblasts following $24 \mathrm{~h}$ exposure to $500 \mu \mathrm{g} / \mathrm{L} \mathrm{Co}^{2+}: \mathrm{Cr}^{3+}$.

\begin{tabular}{|c|c|c|c|c|c|c|c|c|}
\hline \multirow{2}{*}{$\begin{array}{c}\text { KEGG } \\
\text { Pathway }\end{array}$} & \multirow{2}{*}{$\begin{array}{c}\text { KEGG } \\
\text { ID }\end{array}$} & \multirow{2}{*}{$\log _{2} \mathrm{FC}$} & \multicolumn{6}{|c|}{ Genes } \\
\hline & & & PDK1 & PFKFB3 & VEGFA SLC2A1 & PFKFB4 ALDOC & ENO2 EGLN1 & PGK1 \\
\hline $\begin{array}{c}\text { HIF } \\
\text { Signalling }\end{array}$ & 04066 & $4.15 \times 10^{-7}$ & & & & & & \\
\hline $\begin{array}{l}\text { Fructose and } \\
\text { mannose } \\
\text { metabolism }\end{array}$ & 00051 & $8.9 \times 10^{-4}$ & & & & & & \\
\hline $\begin{array}{l}\text { Renal cell } \\
\text { carcinoma }\end{array}$ & 05211 & $3.34 \times 10^{-2}$ & & & & & & \\
\hline
\end{tabular}



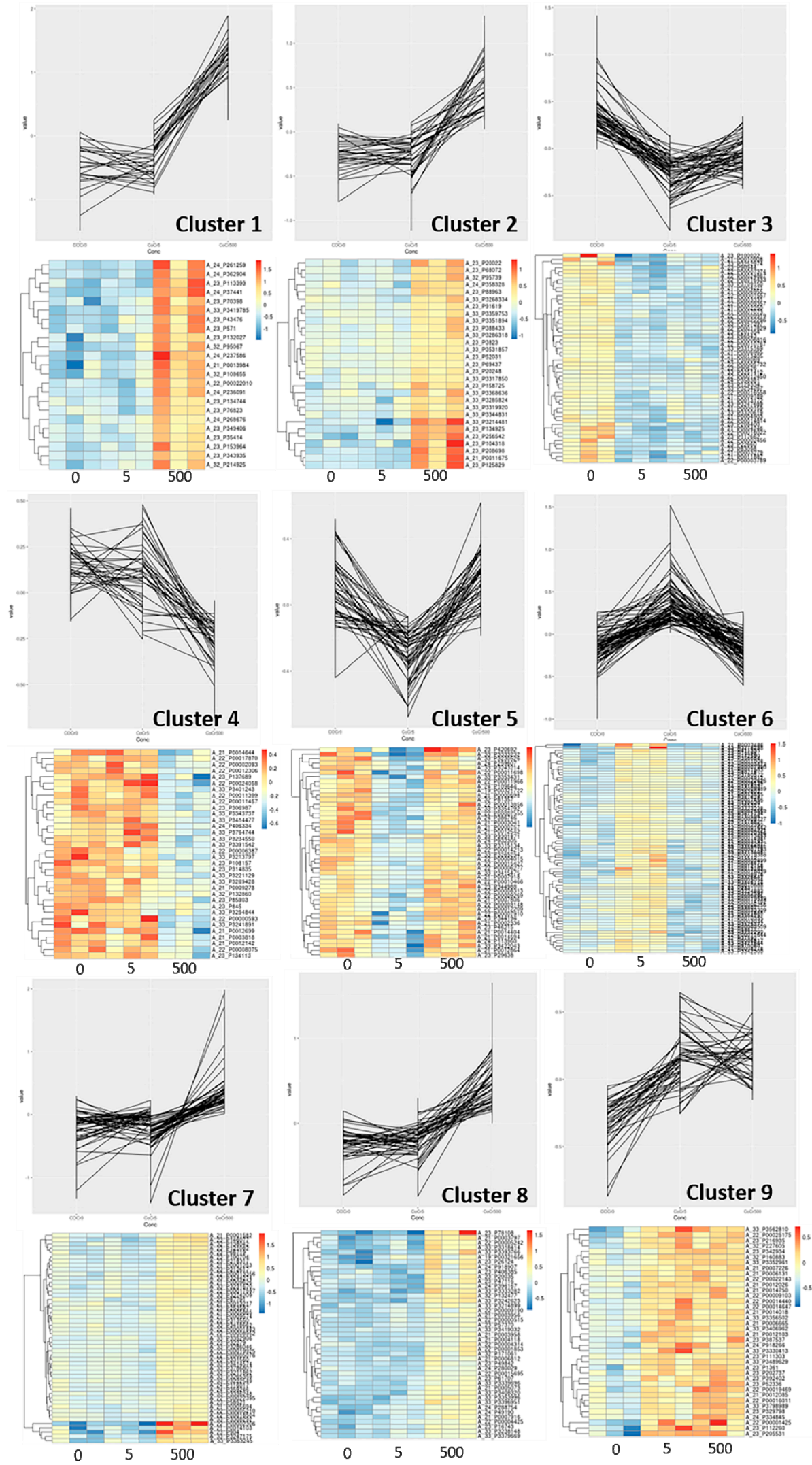

Figure 1. Expression profiles for osteoblast gene clusters with statistically significant expression changes with increasing concentrations of $\mathrm{Co}^{2+}: \mathrm{Cr}^{3+}(0,5$ and $500 \mu \mathrm{g} / \mathrm{L})$. Corresponding heat map for each plot is illustrated underneath. Gene list for each cluster is available in Supplementary Table S1. 


\subsection{Effect of Cobalt and Chromium Exposure on Primary Human Osteoclasts}

For osteoclast precursors exposed to systemic $\mathrm{Co}^{2+}: \mathrm{Cr}^{3+}$ concentration of $5 \mu \mathrm{g} / \mathrm{L}$, 313 genes were down-regulated (Supplementary Table S2). KEGG pathway analyses identified overrepresentation of genes associated with the focal adhesion pathway (KEGG:04510; $P=1.8 \times 10^{-3}$ ) and ECM-receptor interaction (KEGG:04512; $P=6.3 \times 10^{-3}$ ) among others (Figure 2). We also observed down-regulation of genes associated with osteoclast differentiation (DCSTAMP and GPER1; $\log _{2} \mathrm{FC}=-1.87$ and $-1.64, P=2.4 \times 10^{-3}$ and $2.9 \times 10^{-3}$ respectively) and apoptosis (HRK and FAS; $\log _{2} \mathrm{FC}=-1.65$ and $-2.3, P=3.6 \times 10^{-3}$ and $\left.7.3 \times 10^{-3}\right)$. This was accompanied by an increase in genes associated with epigenetic modifications (KMT5C, $\log _{2} \mathrm{FC}=-1.53, P=4.5 \times 10^{-3}$ ) and $\mathrm{Ca}^{2+}$ signaling pathways (ANO3 and SELENOP; $\log _{2} \mathrm{FC}=-1.56$ and 1.87.3, $P=6.4 \times 10^{-3}$ and $9.3 \times 10^{-3}$; Supplementary Table S2).

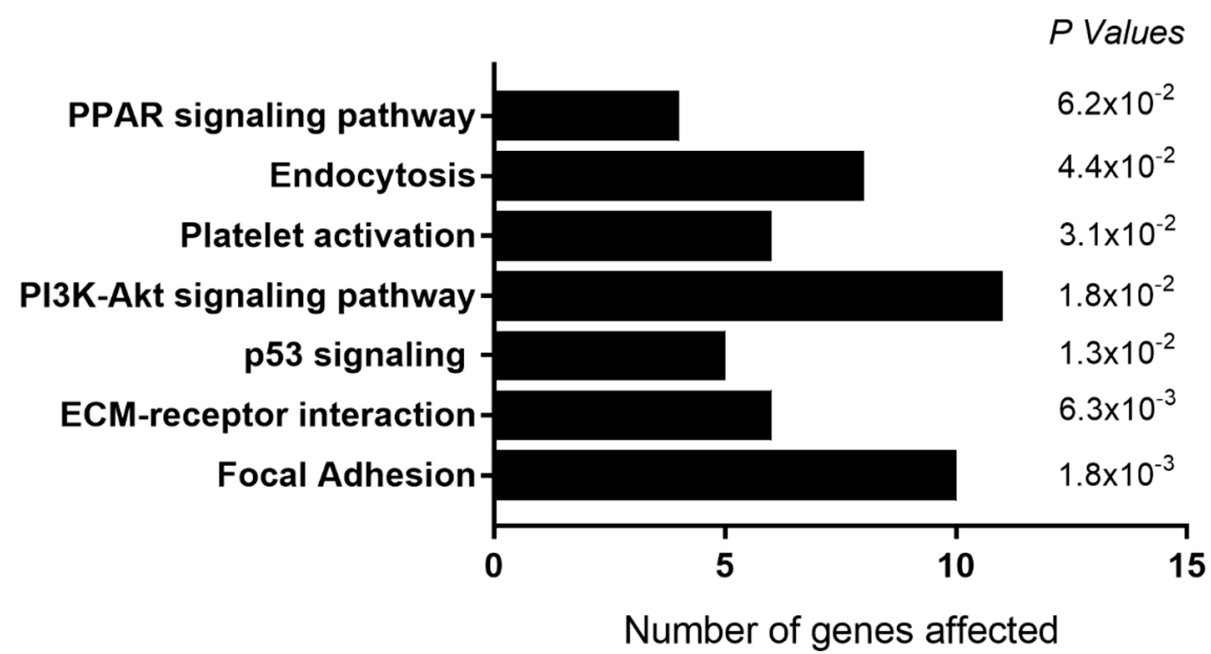

Figure 2. Functional classification of genes down-regulated in osteoclast precursors following exposure to $5 \mu \mathrm{g} / \mathrm{L} \mathrm{Co}^{2+}: \mathrm{Cr}^{3+}$. KEGG pathways that were enriched in the differentially expressed genes, with the number of genes in each pathway and the corresponding $P$ value are illustrated here.

Exposure to higher concentration of $500 \mu \mathrm{g} / \mathrm{L} \mathrm{Co}^{2+}: \mathrm{Cr}^{3+}$ caused a down-regulation in 467 genes, and an up-regulation in 125 genes (Supplementary Table S3). Functional classification identified the down-regulated genes to be overrepresented in the endocytosis pathway (KEGG:04144; $P=9.3 \times 10^{-3}$ ). These include genes involved in both the formation of endosomes $\left(P I P 5 K, \log _{2} \mathrm{FC}=-1.63, P=2.1 \times 10^{-3}\right.$; and $P L D, \log _{2} \mathrm{FC}=-1.59$, $\left.P=1.75 \times 10^{-4}\right)$ and its trafficking $\left(E H D 2, \log _{2} \mathrm{FC}=-1.60, P=1.9 \times 10^{-3}\right.$; and EHD3, $\left.\log _{2} \mathrm{FC}=-1.73, P=8.82 \times 10^{-4}\right)$. Up-regulated genes were associated with the cytokinecytokine receptor interaction pathway (KEGG:04060; $P=1.1 \times 10^{-13}$ ) and TNF signaling pathway (KEGG:04668; $P=3.5 \times 10^{-4}$ ).

Gene probes that showed significant dose-dependent effects with increasing concentrations of $\mathrm{Co}^{2+}: \mathrm{Cr}^{3+}$ formed eight individual clusters (Supplementary Table S4). Functional classification of these gene clusters identified calcium signalling (KEGG:04020; $P=1.3 \times 10^{-3}$ ) and Ras signalling pathway (KEGG:04014; $P=3.6 \times 10^{-3}$ ) to be enriched in Cluster 1, which associated negatively with increasing metal concentrations (Figure 3A). Cluster 4 which positively correlates with increasing metal concentrations (Figure 3B) had the cytokine-cytokine receptor interaction pathway (KEGG:04060; $P=4.7 \times 10^{-2}$ ) enriched which included genes such as IL13RA1 and IFNGR1 that are known to reduce osteoclast activity [11,12]. 

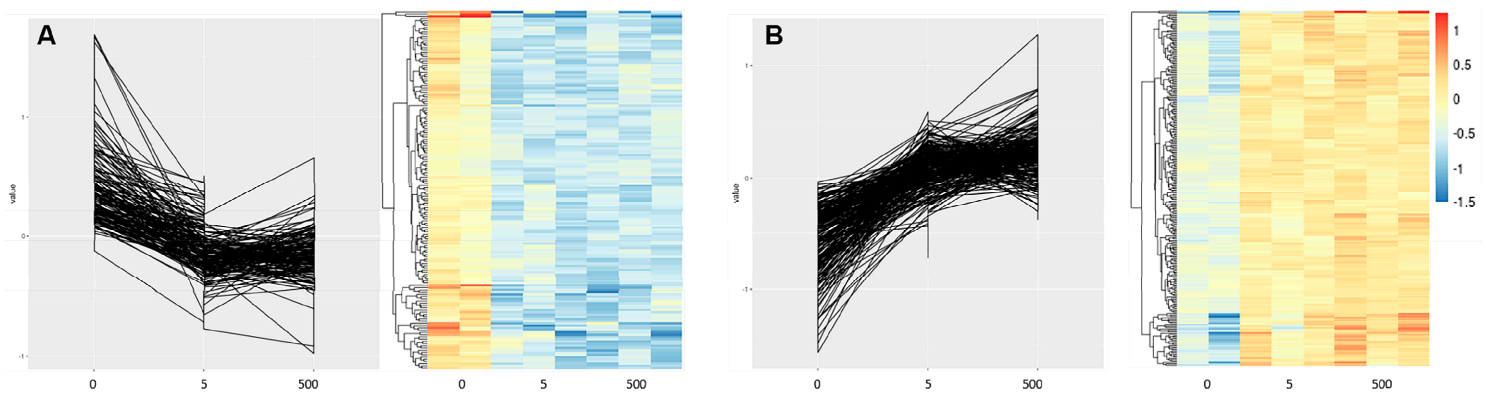

Figure 3. Expression profiles for osteoclast precursor gene clusters with statistically significant expression changes with increasing concentrations of $\mathrm{Co}^{2+}: \mathrm{Cr}^{3+}(0,5$ and $500 \mu \mathrm{g} / \mathrm{L})$. Corresponding heat map for each plot is illustrated underneath. (A) Cluster 1 with genes that are overrepresented in calcium signaling and Ras signaling pathway, and associate negatively to metal concentrations, and (B) Cluster 4 have genes overrepresented in cytokine-cytokine receptor interaction pathway and have positive association with increasing concentrations of metal ions. Gene list for all eight clusters can be found in Supplementary Table S4.

For osteoclast precursors exposed to $\mathrm{CoCr}$ nanoparticles, we observed down-regulation of 525 genes, including genes that associate with the endocytosis pathway (KEGG:04144; $P=1.1 \times 10^{-3}$ ), and those that regulate actin cytoskeleton (KEGG:04810; $P=8.0 \times 10^{-3}$; Supplementary Table S5). There were 121 genes up-regulated that were overrepresented in the transcriptional misregulation in cancer pathway (KEGG:05202; $P=5.9 \times 10^{-4}$ ), including chromatin regulator HMGA2 $\left(\log _{2} \mathrm{FC}=1.14 ; P=2.9 \times 10^{-3}\right)$ and transcription factor HOXA10 $\left(\log _{2} \mathrm{FC}=1.03 ; P=2.98 \times 10^{-5}\right)$.

For mature osteoclasts exposed to systemic $\mathrm{Co}^{2+}: \mathrm{Cr}^{3+}$ concentration of $5 \mu \mathrm{g} / \mathrm{L}, 185$ genes were down-regulated (Supplementary Table S6). Functional classification identified their association with focal adhesion (KEGG: 04510; $P=3.4 \times 10^{-3}$ ), ECM interaction (KEGG:04512; $P=9.5 \times 10^{-3}$ ) and PI3K-Akt signaling pathways (KEGG:04151; $P=4.6 \times 10^{-2}$ ). We also observed down-regulation of similar genes to those observed in osteoclast precursors, and those that osteoclast differentiation (DCSTAMP and GPER1; $\log _{2} \mathrm{FC}=-1.74$ and -1.66 , $P=6.0 \times 10^{-3}$ and $4.2 \times 10^{-3}$ respectively).

At higher concentrations of $500 \mu \mathrm{g} / \mathrm{L} \mathrm{Co}^{2+}: \mathrm{Cr}^{3+}$, as with the lower concentration of $5 \mu \mathrm{g} / \mathrm{L}$, genes from the focal adhesion (KEGG: 04510; $P=3.0 \times 10^{-3}$ ) and PI3K-Akt signaling pathways (KEGG: 04151; $P=2.1 \times 10^{-2}$ ) were down-regulated. Other genes that were associated with osteoclast survival and function that were down-regulated included CSF1 $\left(\log _{2} \mathrm{FC}=-2.38 ; P=3 \times 10^{-4}\right)$ and ITGBL1 $\left(\log _{2} \mathrm{FC}=-1.62 ; P=9 \times 10^{-3}\right.$; Supplementary Table S7). Genes known to play a role in osteoblast differentiation such as WNT5A $\left(\log _{2} \mathrm{FC}=1.42 ; \mathrm{P}=2.03 \times 10^{-6}\right)$ and ATF5 $\left(\log _{2} \mathrm{FC}=1.97 ; P=3.1 \times 10^{-3}\right)$ were up-regulated at this concentration (Supplementary Table S7).

Gene probes that showed significant dose-dependent effects with increasing concentrations of $\mathrm{Co}^{2+}: \mathrm{Cr}^{3+}$ formed nine individual clusters (Supplementary Table S8). Genes from the focal adhesion pathway (KEGG: 04510; $\mathrm{P}=5.0 \times 10^{-2}$, Cluster 6) were found to be enriched from a cluster that negatively associated with increasing metal concentrations (Table 3).

Table 3. KEGG pathways that associate with increasing concentrations of $\mathrm{Co}^{2+}: \mathrm{Cr}^{3+}$.

\begin{tabular}{ccccc}
\hline Pathways & KEGG & Cell Type & Correlation & $p$ Value \\
\hline HIF1- signaling & 04066 & Osteoblasts & Positive & $5.2 \times 10^{-7}$ \\
Glycolysis/Gluconeogenesis & 00010 & Osteoblasts & Positive & $1.02 \times 10^{-6}$ \\
Ca $^{2+}$ signaling & 04020 & Osteoclast precursors & Negative & $1.3 \times 10^{-3}$ \\
Ras signaling & 04014 & Osteoclast precursors & Negative & $3.6 \times 10^{-3}$ \\
Cytokine-cytokine receptor interaction & 04060 & Osteoclast precursors & Positive & $4.7 \times 10^{-2}$ \\
Focal Adhesion & 04510 & Mature osteoclasts & Negative & $5.0 \times 10^{-2}$ \\
\hline
\end{tabular}


Focal adhesion (KEGG: 04510; $P=5.4 \times 10^{-4}$ ) and endocytosis (KEGG:04144; $P=2.5 \times 10^{-3}$ ) were the primary pathways down-regulated in mature osteoclasts exposed to CoCr nanoparticles. Specifically, integrins ITGA3 $\left(\log _{2} \mathrm{FC}=-1.03 ; P=4.9 \times 10^{-3}\right)$ and ITGB3 $\left(\log _{2} \mathrm{FC}=-1.89 ; P=8.9 \times 10^{-4}\right)$, and cytoskeletal genes $P X N\left(\log _{2} \mathrm{FC}=-1.36\right.$; $\left.P=1.27 \times 10^{-4}\right)$ and FLNB $\left(\log _{2} \mathrm{FC}=-1.41 ; \mathrm{P}=1.17 \times 10^{-4}\right)$ were down-regulated in the focal adhesion pathway. Endocytosis associated genes included PIP5K $(\log 2 \mathrm{FC}=-2.1$; $\left.P=6.3 \times 10^{-4}\right)$, EHD2 $\left(\log _{2} \mathrm{FC}=-2.92 ; P=5.9 \times 10^{-4}\right)$, EHD3 $\left(\log _{2} \mathrm{FC}=-1.94 ;\right.$ $\left.P=5.8 \times 10^{-4}\right)$, and RAB11FIP1 $\left(\log _{2} \mathrm{FC}=-1.52 ; P=4.8 \times 10^{-4}\right) . I L 6\left(\log _{2} \mathrm{FC}=1.51 ;\right.$ $\left.P=7.06 \times 10^{-4}\right)$ and SELENOP $\left(\log _{2} \mathrm{FC}=2.08 ; P=2 \times 10^{-3}\right)$ both of which are implicated in osteoclast activity and $\mathrm{Ca}^{2+}$ homeostasis were up-regulated (Supplementary Table S9).

\subsection{Effect of Cobalt and Chromium Exposure on Primary Human Osteoblasts on Prosthesis Surfaces}

For osteoblasts grown on prosthesis surfaces in the absence of metal exposure, we did not observe significant alteration in gene expression between cells on GB and Ti surfaces. For cells grown on HA surfaces, we observed an up-regulation in 40 genes compared to cells grown on GB surfaces. While no KEGG pathway was identified for these genes, we observed increased expression in BMP2 $\left(\log _{2} \mathrm{FC}=2.6 ; P=4.71 \times 10^{-7}\right)$ and SPP1 $\left(\log _{2} \mathrm{FC}=2.78 ; P=3.9 \times 10^{-4}\right)$ which are associated with increased osteoblast differentiation (Supplementary Table S10). When comparing cells on HA surfaces to those on Ti surfaces, we observed 69 genes down-regulated on Ti surfaces (Supplementary Table S11), of which 12 were common to those expressed at lower levels on GB surfaces including $B M P 2$ and SPP1.

Following metal exposure at periprosthetic concentrations of $\mathrm{Co}^{2+}: \mathrm{Cr}^{3+}(1000 \mu \mathrm{g} / \mathrm{L})$, the expression profile for osteoblasts on GB surfaces was similar to that of cells on $\mathrm{Ti}$ surfaces with only three genes differentially regulated. We observed an up-regulation of TSPAN13 $\left(\log _{2} \mathrm{FC}=1.13 ; P=9.75 \times 10^{-4}\right)$, GUCY2G $\left(\log _{2} \mathrm{FC}=1.01 ; P=9.77 \times 10^{-4}\right)$ and UBE2DNL $\left(\log _{2} \mathrm{FC}=1.02 ; P=9.79 \times 10^{-3}\right)$ for cells on GB surfaces compared to those on Ti surfaces. In comparison, cells on HA surfaces had 69 probes down-regulated with no specific KEGG pathway enriched for the down-regulated genes (Supplementary Table S12). Several genes that were down-regulated on HA surfaces are known to play a vital role in cell cycle progression and mitosis including CCNB2 $\left(\log _{2} \mathrm{FC}=-1.3 ; P=3.5 \times 10^{-3}\right)$, KIF22 $\left(\log _{2} \mathrm{FC}=-1.33 ; P=1.1 \times 10^{-3}\right), C D C A 2\left(\log _{2} \mathrm{FC}=1.10 ; P=5.2 \times 10^{-3}\right)$ and $C E N P N\left(\log _{2} \mathrm{FC}=-1.18 ; P=5.5 \times 10^{-3}\right)$. Genes that were up-regulated on HA surfaces compared to GB surfaces included those that influence osteoblast differentiation including $B M P 2\left(\log _{2} \mathrm{FC}=2.66 ; P=2.56 \times 10^{-6}\right), S P P 1\left(\log _{2} \mathrm{FC}=2.61 ; P=3.09 \times 10^{-4}\right)$ and $O M D$ $\left(\log _{2} \mathrm{FC}=1.15 ; P=7.1 \times 10^{-3}\right)$. We also observed genes from the Glycerolipid metabolism pathway (KEGG: 00561; $P=7.09 \times 10^{-3}$ ) to be up-regulated in cells from HA surfaces compared to GB (Supplementary Table S12).

In the presence of periprosthetic concentrations of $\mathrm{Co}^{2+}: \mathrm{Cr}^{3+}$ ions $(1000 \mu \mathrm{g} / \mathrm{L})$, osteoblast grown on HA surfaces had higher expression of genes associated with osteoblast differentiation and mineralization compared to cells on Ti surfaces, similar to those observed with GB surfaces. We observed an increase in $B M P 2\left(\log _{2} \mathrm{FC}=2.71 ; P=2.12 \times 10^{-6}\right)$ and SPP1 $\left(\log _{2} \mathrm{FC}=3.04 ; P=8.58 \times 10^{-5}\right)$ expression; inorganic pyrophosphate transporter ANKH $\left(\log _{2} \mathrm{FC}=1.1 ; P=3.9 \times 10^{-3}\right)$, and extracellular matrix protein $M G P\left(\log _{2} \mathrm{FC}=2.22\right.$; $P=7.8 \times 10^{-3}$ ) which regulate mineralization. $R A B 27 B$, a gene responsible for vesicular trafficking was also up-regulated on HA surfaces $\left(\log _{2} \mathrm{FC}=1.4 ; P=9.71 \times 10^{-5}\right.$; Supplementary Table S13).

Following $\mathrm{CoCr}$ nanoparticle exposure, we did not observe large-scale alterations in gene expression between osteoblasts on GB surfaces and Ti surfaces. The only differential expression we observed was a down-regulation in $M X 1\left(\log _{2} \mathrm{FC}=-1.39 ; P=3.7 \times 10^{-3}\right)$ and an up-regulation in GRIN3A $\left(\log _{2} \mathrm{FC}=-1.12 ; P=1.1 \times 10^{-3}\right)$ expression in cells on GB surfaces compared to Ti surfaces. Genes enriched in the necroptosis pathway (KEGG: $04217 ; P=1.18 P \times 10^{-5}$ ) were down-regulated for cells on HA surfaces compared to GB surfaces. Other pathways that were enriched with the down-regulated genes included 
alcoholism (KEGG: 05034; $P=6.89 \mathrm{P} \times 10^{-7}$ ) and Systemic lupus erythematosus (KEGG: 05322; $P=5.64 \times 10^{-8}$ ). Specifically, several genes from the $\mathrm{H} 2$ and $\mathrm{H} 3$ histone family that are common between the enriched pathways were down-regulated in osteoblasts on HA surfaces (Supplementary Table S14). A similar set of genes to those observed following ionic exposure, had higher expression on HA surfaces compared to both GB and Ti surfaces, including BMP2, SPP1 and ANKH (Supplementary Tables S14 and S15).

\section{Discussion}

The detrimental effect of prostheses-derived $\mathrm{Co}$ and $\mathrm{Cr}$ debris on the survival and function of bone cells is well established. However, little is known about the molecular mechanisms that mediate these effects. In this study, we used genome-wide microarrays to obtain a comprehensive insight into the response of primary human osteoblasts and osteoclasts at clinically relevant concentrations of $5 \mu \mathrm{g} / \mathrm{L}$ and $500 \mu \mathrm{g} / \mathrm{L} \mathrm{Co}$ and $\mathrm{Cr}$ ions representing systemic and periprosthetic metal exposure in the setting of a well-functioning prosthesis, as well as CoCr nanoparticles. We also identify gene clusters and KEGG pathways for which the expression correlates with increasing $\mathrm{Co}^{2+}: \mathrm{Cr}^{3+}$ concentrations (Table 3). Furthermore, we describe the effects of routinely used grit-blasted, plasmasprayed titanium and hydroxyapatite prosthetic surfaces on primary osteoblast gene expression without, and following, metal exposure.

\subsection{Systemic Levels of Metal Exposure Inhibit Osteoclast Differentiation and Function}

Total-body bone mineral density has been reported to be $5 \%$ higher in patients with well-functioning MoM hip resurfacing with median systemic concentrations of $\mathrm{Co}$ and $\mathrm{Cr}$ at $1.48 \mu \mathrm{g} / \mathrm{L}$ and $2.5 \mu \mathrm{g} / \mathrm{L}$ respectively, compared to those with conventional metal-onpolyethylene (MoP) prosthesis with >10 times lower metal ion levels [3]. This is accompanied by a decrease in serum markers of osteoclast and osteoblast activity suggesting reduced bone turnover. The results from this current study are consistent with these observations, and show down-regulation of genes associated with osteoclast differentiation and function in osteoclast precursors as well as mature osteoclasts at a comparable concentration of $5 \mu \mathrm{g} / \mathrm{L} \mathrm{Co}^{2+}: \mathrm{Cr}^{3+}$. This, accompanied by lower transcription of genes associated with the focal adhesion and ECM interaction pathways that promote osteoclast differentiation via increasing RANK expression [13], further supports a reduction in osteoclast activity at systemic concentrations of metal ions.

The absence in alterations of gene expression in osteoblasts at this concentration suggests that the reduced systemic osteoblast activity observed in patients may be a result of de-coupling in osteoclast-mediated osteoblast function [14,15], and not a direct effect on osteoblasts themselves. This is further supported by previous reports that show no significant effect on osteoblast survival and function at equivalent concentrations [7]. Taken together, our data suggests that the systemic increased total-body bone mineral density may primarily be due to the direct inhibitory effects of metal ions on osteoclast differentiation and resorptive function.

\subsection{Periprosthetic Levels of Metal Exposure Inhibit Differentiation and Function of Osteoblasts and Osteoclasts}

At higher concentrations of $500 \mu \mathrm{g} / \mathrm{L} \mathrm{Co}^{2+}: \mathrm{Cr}^{3+}$, equivalent to those observed in the periprosthetic milieu [16], increased expression of genes such as PDK-1, VEGFA and BNIP3 that are associated with HIF-1 signaling pathway was observed in osteoblasts. Cobalt chloride is a well-recognized hypoxia mimetic that stabilizes HIF- $1 \alpha$ and therefore this is an expected observation $[17,18]$. Nevertheless, the data is consistent with a recent clinical study that reported up-regulation of HIF- $1 \alpha$ target genes in the periprosthetic tissue of patients with MoM hip replacement undergoing revision surgery [19]. HIF- $1 \alpha$ stabilization seems to be a localized periprosthetic effect as a separate study did not observe any correlation in serum HIF1 $\alpha$ levels in MoM patients with higher chronic metal exposure [20]. Additionally, the absence of an effect on HIF-1 signaling in osteoclast precursors or mature osteoclasts suggests that hypoxic signaling may be limited to cells of mesenchymal origin. 
This is supported by a previous study in which we observed lower uptake of $\mathrm{Co}^{2+}$ in mature osteoclasts compared to human osteoblast-like cells [21]. Furthermore, genes associated with fructose and mannose pathways (PFKB3, PFKB4 and ALDOC, Table 2) that were up-regulated in osteoblasts are likely to be secondary to HIF- $1 \alpha$ signaling, and represent a shift to a more glycolytic metabolic mode to sustain cellular energy needs, as shown previously $[22,23]$. The evidence for the effects of hypoxic signaling in osteoblasts is conflicting. Utting et al. (2006) show that hypoxic signaling inhibits differentiation and bone-forming capacity of primary rat osteoblasts [24]. Conversely, a study in murine models demonstrated that stabilization of HIF- $1 \alpha$ and the shift to glycolytic metabolism increases osteoblast numbers and induces bone formation [25]. In our previous study, we observed that exposure to $500 \mu \mathrm{g} / \mathrm{L} \mathrm{Co}^{2+}: \mathrm{Cr}^{3+}$ does increase osteoblast mineralization in vitro, without affecting cell survival [7]. However, the effect of hypoxic signaling on the quality of the mineralized matrix remains unclear. In a recent study, Stegen et al. (2019) show that while stabilization of HIF- $1 \alpha$ increases collagen crosslinking and mineral deposition, the metabolism of collagen is altered leading to skeletal dysplasia [26].

A small proportion of patients with MoM hip replacement present with a local inflammatory reaction to metal debris referred to as ARMD, characterised by macrophage and lymphocytic infiltrate $[27,28]$. In osteoclast precursors, which are cells derived from the same myeloid lineage as macrophages, we observe an up-regulation of immune chemoattractants (CCL1 and CCL23), and inflammatory cytokines (IL-1 $\beta$ and IL-6) from the chemokine-chemokine signaling pathway that may partially explain the mechanism for ARMD. While no studies have investigated the effect of combined $\mathrm{CoCr}$ metal exposure on gene expression in these cells, a previous study observed an up-regulation in cytokine and chemokine genes including $I L-1 \beta$ and $I L-6$ in peripheral blood monocytes following $\mathrm{Co}^{2+}$ exposure alone [29]. Endocytosis and membrane trafficking were shown to be essential in fusion of osteoclast precursors as well as in maintaining resorption activity in mature osteoclasts $[30,31]$. Down-regulation of genes associated with endocytic and actin cytoskeletal pathways following ionic and particulate metal exposure suggests reduced osteoclast differentiation from its precursors in the periprosthetic environment. Additionally, a similar reduction in differentiation and function of mature osteoclasts is suggested with down-regulation of focal adhesion, endocytosis and PI3K-AKT pathways [13,32-34].

Taken together with the effect on osteoblasts, the data suggests that bone turnover may be inhibited in the periprosthetic microenvironment, with implications for osseointegration and eventual failure of the prosthesis.

\subsection{Pathways with a Dose-Dependent Effects to Metal Ions}

In this study, we identified gene clusters for both osteoblasts and osteoclasts, with significant dose-dependent correlations with increasing concentrations of $\mathrm{Co}^{2+}: \mathrm{Cr}^{3+}$. The positive correlation for genes associated with HIF-1 signaling (such as VEGFA, PDK1, ENO2 and SLC2A1) and Glycolysis/Gluconeogenesis pathways (PGM1, TPI1 and PGK1) with metal exposure in osteoblasts confirm them as the primary response in these cells. This dose-dependent increase in the genes from the Glycolysis/Gluconeogenesis pathway is consistent with a recent study that showed an increase in glycolytic parameters including increased lactate production in macrophages exposed to $\mathrm{Co}^{2+}$ and $\mathrm{Cr}^{3+}$. The study also demonstrated that this shift to glycolysis is downstream of HIF-1 $\alpha$ stabilization, an effect primarily attributed to $\mathrm{Co}^{2+}[18]$.

Similarly, genes from the cytokine-cytokine receptor interaction pathway (CXCL4, CXCR5, IL13RA1, CD27) in osteoclast precursors and focal adhesion pathways (DIAPH1, $P X N$, and CCND1) in mature osteoclasts positively correlated with metal exposure. The dose-dependent changes in the expression of these genes provides us with a possible gene-panel for which subtle changes in expression may serve as an early marker for $\mathrm{CoCr}$ metal toxicity. 


\subsection{Response of Osteoblasts to Prosthetic Surfaces and Metal Exposure}

Prosthetic surfaces are routinely modified topographically or chemically to make them more osseoconductive and promote osseointegration. GB, Ti and HA coating are some of the most commonly used alterations of prosthetic surfaces. In a previous study, we reported increased osteoblast differentiation and mineralization on HA surfaces compared to GB and Ti surfaces, and a protective effect on their osteogenic activity in the presence of $\mathrm{CoCr}$ ions and nanoparticles [7]. Here we show that HA surfaces, in comparison to GB and Ti surfaces, consistently promote expression of $B M P 2$ in osteoblasts which is known to increase alkaline phosphatase activity and mineralization in an autocrine manner [35]. This increase in BMP2 expression on HA surfaces seems to be a conserved response with studies showing its up-regulation in smooth muscle cells and periodontal ligament cells when cultured on HA surfaces [36,37].

Even with exposure to periprosthetic concentrations of $\mathrm{CoCr}$ ions and nanoparticles, $B M P 2$ and FOSB expression that mediate osteoblast differentiation, and SPP1 (osteopontin) a marker for mature osteoblasts, were consistently up-regulated. This, accompanied by a reduction in genes associated with necroptosis (HIST2H3A, HIST1H2AM, and HIST1H2AK) and cell cycle progression (CCNB2 and $C D C A 2)$, suggests that osteoblasts on HA surfaces possess a pro-survival and differentiation state compared to those grown on GB and Ti surfaces, with implications for osseointegration. Indeed, these results translate clinically. In the National Joint Registry for England and Wales, the largest joint replacement clinical audit in the world, the 5-year revision rates for hydroxyapatite-coated Birmingham and Adept hip resurfacing systems are $3.66 \%$ (95\% CI; 3.42-3.92) and 4.52\% (3.87-5.27) respectively, compared to $8.3 \%$ (6.93-9.93) for Conserve Plus and 5.47\% (4.48-6.66) for the Durom system that use a plasma-sprayed titanium coating [38]. Finally, the up-regulation of glutamate receptor GRIN3A on GB surfaces compared to Ti surfaces may explain the increased mineralization observed on these surfaces in vitro [7]. Glutamate signaling was indeed shown to increase osteoblast differentiation and function [39], and the up-regulation of GRIN3A may partly be a result of differential cell adhesion to the different surface roughness of the two materials [40].

Our study also has limitations. While the high threshold for differentially expressed genes used in this study gives us confidence in our findings, validation of transcripts for select genes using RT-PCR, and the resultant proteins with western blotting, would be useful. Furthermore, investigating gene responses for osteoblasts and osteoclasts in isolation although vital to discern direct effects of metal exposure, discounts the complex inter-cellular coupling that exists between osteoblasts and osteoclasts to maintain bone homeostasis, and using co-culture systems or in silico modeling could help better understand tissue-level effects. Finally, the use of $\mathrm{Co}$ and $\mathrm{Cr}$ ion combinations at the ratio of 1:1 is an approximation of the clinical setting after hip resurfacing. This may differ for MoM total hip replacements and vary between patients.

In conclusion, this study provides a comprehensive mechanistic understanding of the direct effects prosthesis derived $\mathrm{Co}$ and $\mathrm{Cr}$ have on primary human osteoblasts and osteoclasts in both the systemic and local periprosthetic environment. Furthermore, for the first time, to the best of our knowledge, several gene clusters and pathways that are regulated in a dose-dependent manner in bone cells are identified here, which could serve as early markers for metal toxicity. Finally, we provide a mechanistic basis for the improved clinical performance of hydroxyapatite-coated prostheses.

\section{Materials and Methods}

\subsection{Metal Ion Preparation and Treatment}

Cobalt (II) hexahydrate $(\mathrm{CoCl} 2.6 \mathrm{H} 2 \mathrm{O})$ and chromium (III) chloride hexahydrate ( $\mathrm{CrCl} 3.6 \mathrm{H} 2 \mathrm{O}$ ) (Fluka, Gillingham, UK) served as salts for $\mathrm{Co}^{2+}$ and $\mathrm{Cr}^{3+}$, respectively. For each metal salt, $0.2 \mathrm{M}$ stock solutions were prepared in sterile water and serially diluted to $100 \times$ working concentrations. Subsequently, equal volumes of $\mathrm{Co}^{2+}$ and $\mathrm{Cr}^{3+}$ solutions $\left(\mathrm{Co}^{2+}: \mathrm{Cr}^{3+}\right)$ were added to culture media to get the final treatment concentrations. The 
stability of these metal ions in culture media has been confirmed previously using flameatomic absorption spectroscopy [4]. Control treatment contained equivalent volume of sterile distilled water to maintain conditions and are referred to as $0 \mu \mathrm{g} / \mathrm{L}$ treatments.

$\mathrm{Co}$ and $\mathrm{Cr}_{2} \mathrm{O}_{3}$ nanoparticles (a kind gift from Dr Ferdinand Lali, Imperial College, London, UK) were $40 \mathrm{~nm}$ and $30 \mathrm{~nm}$ in size respectively. Both osteoblasts and osteoclasts were treated with 100 nanoparticles each of $\mathrm{Co}$ and $\mathrm{Cr}_{2} \mathrm{O}_{3}$ per cell (CoCr nanoparticles), based on their seeding densities. Using the specific surface area (SSA) of the nanoparticles $\left(50 \mathrm{~m}^{2} / \mathrm{gm}\right.$ for $\mathrm{Co}$, and $140 \mathrm{~m}^{2} / \mathrm{gm}$ for $\left.\mathrm{Cr}_{2} \mathrm{O}_{3}\right)$, and the surface area of a sphere $\left(4 \pi \mathrm{r}^{2}\right)$, we deduced the approximate particle number per gram of nanoparticles. These calculations were used to form a $1000 \times$ stock of the working concentration in $100 \%$ ethanol. Prior to treatments, the suspension was sonicated for $10 \mathrm{~min}$ to disaggregate the particles and diluted in osteogenic media to obtain the working concentration. Control treatment contained equivalent volume of ethanol to maintain conditions.

\subsection{Primary Human Osteoblast Culture}

Primary human osteoblasts were obtained from trabecular bone explants of patients undergoing joint replacement surgery following approval by South Yorkshire and Northern Derbyshire Musculoskeletal Biobank and approved by the National Research Ethics Service (15/SC/0132; Study reference: SYNDMB031), and all patients gave informed written consent prior to participation [41]. Briefly, the trabecular bone fragments were diced and washed thoroughly with PBS and cultured in petridishes with complete media containing DMEM GlutaMAX supplemented with $10 \%$ FBS, $100 \mathrm{U} / \mathrm{mL}$ penicillin, $100 \mu \mathrm{g} / \mathrm{mL}$ streptomycin and $2.5 \mu \mathrm{g} / \mathrm{mL}$ Amphotericin-B (Gibco, Paisley, UK). After a week, the media was replaced twice weekly for a further $4-6$ weeks till the explant cultures reached confluence. The osteoblast-like phenotype of these cells was confirmed by assessing their alkaline phosphatase activity and their ability to mineralize in vitro, and was described previously [7]. Subsequently, cells were cultured in vitro on tissue culture plates, or on GB, Ti and HA coated prosthesis surfaces (supplied by JRI Orthopaedics Ltd., Sheffield, UK) that better mimic the periprosthetic physiological setting and were manufactured using the same processes as used commercially.

Osteoblasts grown in tissue culture plates were treated with a combination of 0,5 , and $500 \mu \mathrm{g} / \mathrm{L}$ of $\mathrm{Co}^{2+}: \mathrm{Cr}^{3+}$ to mimic the systemic concentrations observed following metal-onmetal hip resurfacing. For cells grown on prosthetic surface, periprosthetic concentrations of $1000 \mu \mathrm{g} / \mathrm{L} \mathrm{Co}^{2+}: \mathrm{Cr}^{3+}$ were used. In both cases, the osteoblasts were exposed to the different concentrations of metal ions for $24 \mathrm{~h}$. Previous clinical reports on the levels of circulating and periprothetic $\mathrm{Co}$ and $\mathrm{Cr}$ has informed the use of these concentrations in this study [42-45].

\subsection{Primary Human Osteoclast Culture}

Primary human osteoclasts were generated as described previously from human peripheral blood of healthy volunteers following research ethics committee approval [46]. Briefly, CD14+ enriched monocyte population was isolated from peripheral blood and seeded onto sterile dentine disks in osteoclastogenic media containing $\alpha$-MEM GlutaMAX supplemented with $10 \%$ FBS, $100 \mathrm{U} / \mathrm{mL}$ penicillin, $100 \mu \mathrm{g} / \mathrm{mL}$ streptomycin (Gibco, Paisley, UK), $25 \mathrm{ng} / \mathrm{mL}$ M-CSF (R\&D Systems, Abingdon, UK) and $30 \mathrm{ng} / \mathrm{mL}$ RANKL (R\&D Systems, Abingdon, UK), and cultured in humidified incubator at $37^{\circ} \mathrm{C}$ and $7 \% \mathrm{CO}_{2}$. To investigate the effects of metal ions on developing osteoclasts, the metal ion treatments were added at day 3, and replaced every 2-3 days until the onset of resorption. To investigate the effects on mature osteoclasts, metal ion treatments were added for $24 \mathrm{~h}$ after the onset of resorption (typically day 14).

Both developing and mature osteoclasts were treated with 0,5 and $500 \mu \mathrm{g} / \mathrm{L}$ of $\mathrm{Co}^{2+}: \mathrm{Cr}^{3+}$ to mimic systemic concentrations observed following metal-on-metal hip resurfacing. The developing osteoclasts were treated continuously til $24 \mathrm{~h}$ after the onset of resorption while mature osteoclasts were treated once for $24 \mathrm{~h}$ following the onset of resorption. 


\subsection{RNA Extraction and Gene Expression}

Following exposure to metal ion treatments, the cells were washed twice with icecold PBS and total RNA extracted using the RNeasy Extractions Kits (Qiagen, Hilden, Germany) as per manufacturer's protocol and the quality checked using the Agilent 2200 TapeStation (Agilent Technologies, Santa Clara, CA, USA). Gene expression profiling was performed using Agilent SureprintG3 Gene Expression Microarrays $(8 \times 60 \mathrm{~K}$ format $)$ (Agilent Technologies, Santa Clara, CA, USA). Total RNA from was labeled with cyanine3 CTP and hybridized to the array as per manufacturer's instructions, the arrays read using the Agilent Microarray Scanner, and the data extracted with Feature Extraction v10.7 (Agilent Technologies, Santa Clara, CA, USA).

\subsection{Data Analyses}

The microarray data were imported into $\mathrm{R}$ using the 'limma' Bioconductor package for quality assessment and processing [47]. Three arrays were removed from the Osteoclasts dataset due to significant spatial artifacts present on the raw images. Background correction was performed using the normexp method in limma and signal between arrays was calibrated using quantile normalization. The normalized data were then filtered to the set of $50 \%$ most variable probes in order to increase the power to detect differential expression [48]. Differentially expressed probes were identified using a linear model approach followed by empirical Bayes shrinkage and the threshold was set at $\log _{2} \mathrm{FC}>1$ and $P<0.001$ [47]. DAVID (Ver. 6.8) was used to conduct KEGG enrichment analysis of differentially expressed genes $[49,50]$. The Benjamini-Hochberg corrected $p$ value $<0.05$ was set as the threshold for statistically significant enrichment. In a separate analysis, genes with an association between expression level and concentration were identified using the maSigPro Bioconductor package [51].

Supplementary Materials: The following are available online at https:/ /www.mdpi.com/article/10 .3390/ijms22105225/s1, Supplementary Tables S1-S15.

Author Contributions: Conceptualization, K.M.S., J.M.W. and A.G.; methodology, K.M.S. and M.J.D.; writing—original draft preparation, K.M.S. and M.J.D.; writing—review and editing, K.M.S, M.J.D., J.M.W. and A.G.; supervision, J.M.W. and A.G.; funding acquisition, J.M.W. and A.G. All authors have read and agreed to the published version of the manuscript.

Funding: This study was funded by Orthopaedic Research UK grant (Grant number: 517). KMS was supported by Orthopaedic Research UK (Grant number: 517).

Institutional Review Board Statement: Not applicable.

Informed Consent Statement: Informed consent was obtained from all subjects involved in the study.

Acknowledgments: This research was supported by the NIHR Sheffield Biomedical Research Centre (BRC)/NIHR Sheffield Clinical Research Facility (CRF). The views expressed are those of the author(s) and not necessarily those of the NHS, the NIHR or the Department of Health and Social Care (DHSC).

Conflicts of Interest: The authors declare no conflict of interest.

\section{References}

1. Smith, A.J.; Dieppe, P.; Howard, P.W.; Blom, A.W. Failure rates of metal-on-metal hip resurfacings: Analysis of data from the National Joint Registry for England and Wales. Lancet 2012, 380, 1759-1766. [CrossRef]

2. Smith, A.J.; Dieppe, P.; Vernon, K.; Porter, M.; Blom, A.W. Failure rates of stemmed metal-on-metal hip replacements: Analysis of data from the National Joint Registry of England and Wales. Lancet 2012, 379, 1199-1204. [CrossRef]

3. Prentice, J.R.; Clark, M.J.; Hoggard, N.; Morton, A.C.; Tooth, C.; Paley, M.N.; Stockley, I.; Hadjivassiliou, M.; Wilkinson, J.M. Metal-on-Metal Hip Prostheses and Systemic Health: A Cross-Sectional Association Study 8 Years after Implantation. PLoS ONE 2013, 8, e66186. [CrossRef] [PubMed]

4. Andrews, R.E.; Shah, K.M.; Wilkinson, J.M.; Gartland, A. Effects of cobalt and chromium ions at clinically equivalent concentrations after metal-on-metal hip replacement on human osteoblasts and osteoclasts: Implications for skeletal health. Bone 2011, 49, 717-723. [CrossRef] [PubMed] 
5. Posada, O.M.; Tate, R.J.; Grant, M.H. Effects of CoCr metal wear debris generated from metal-on-metal hip implants and Co ions on human monocyte-like U937 cells. Toxicol. In Vitro 2015, 29, 271-280. [CrossRef]

6. Shah, K.M.; Orton, P.; Mani, N.; Wilkinson, J.M.; Gartland, A. Osteocyte physiology and response to fluid shear stress are impaired following exposure to cobalt and chromium: Implications for bone health following joint replacement. J. Orthop. Res. 2016, 35, 1716-1723. [CrossRef]

7. Shah, K.M.; Wilkinson, J.M.; Gartland, A. Cobalt and chromium exposure affects osteoblast function and impairs the mineralization of prosthesis surfaces in vitro. J. Orthop. Res. 2015, 33, 1663-1670. [CrossRef] [PubMed]

8. Tkaczyk, C.; Huk, O.L.; Mwale, F.; Antoniou, J.; Zukor, D.J.; Petit, A.; Tabrizian, M. Effect of chromium and cobalt ions on the expression of antioxidant enzymes in human U937 macrophage-like cells. J. Biomed. Mater. Res. Part A 2010, 94, 419-425. [CrossRef]

9. Pemmari, A.; Leppänen, T.; Paukkeri, E.-L.; Eskelinen, A.; Moilanen, T.; Moilanen, E. Gene expression in adverse reaction to metal debris around metal-on-metal arthroplasty: An RNA-Seq-based study. J. Trace Elements Med. Biol. 2018, 48, 149-156. [CrossRef] [PubMed]

10. Drynda, A.; Drynda, S.; Kekow, J.; Lohmann, C.H.; Bertrand, J. Differential Effect of Cobalt and Chromium Ions as Well as CoCr Particles on the Expression of Osteogenic Markers and Osteoblast Function. Int. J. Mol. Sci. 2018, 19, 3034. [CrossRef]

11. Palmqvist, P.; Lundberg, P.; Persson, E.; Johansson, A.; Lundgren, I.; Lie, A.; Conaway, H.H.; Lerner, U.H. Inhibition of Hormone and Cytokine-stimulated Osteoclastogenesis and Bone Resorption by Interleukin-4 and Interleukin-13 Is Associated with Increased Osteoprotegerin and Decreased RANKL and RANK in a STAT6-dependent Pathway. J. Biol. Chem. 2006, 281, 2414-2429. [CrossRef]

12. Takayanagi, H.; Ogasawara, K.; Hida, S.; Chiba, T.; Murata, S.; Sato, K.; Takaoka, A.; Yokochi, T.; Oda, H.; Tanaka, K.; et al. T-cell-mediated regulation of osteoclastogenesis by signalling cross-talk between RANKL and IFN-gamma. Nature 2000, 408, 600-605. [CrossRef] [PubMed]

13. Mochizuki, A.; Takami, M.; Miyamoto, Y.; Nakamaki, T.; Tomoyasu, S.; Kadono, Y.; Tanaka, S.; Inoue, T.; Kamijo, R. Cell Adhesion Signaling Regulates RANK Expression in Osteoclast Precursors. PLoS ONE 2012, 7, e48795. [CrossRef] [PubMed]

14. Ma, Q.; Liang, M.; Wu, Y.; Ding, N.; Duan, L.; Yu, T.; Bai, Y.; Kang, F.; Dong, S.; Xu, J.; et al. Mature osteoclast-derived apoptotic bodies promote osteogenic differentiation via RANKL-mediated reverse signaling. J. Biol. Chem. 2019, 294, 11240-11247. [CrossRef] [PubMed]

15. Sims, N.A.; Martin, T.J. Coupling Signals between the Osteoclast and Osteoblast: How are Messages Transmitted between These Temporary Visitors to the Bone Surface? Front. Endocrinol. 2015, 6, 41. [CrossRef] [PubMed]

16. Davda, K.; Lali, F.V.; Sampson, B.; Skinner, J.A.; Hart, A.J. An analysis of metal ion levels in the joint fluid of symptomatic patients with metal-on-metal hip replacements. J. Bone Jt. Surg. 2011, 93, 738-745. [CrossRef] [PubMed]

17. Yuan, Y.; Hilliard, G.; Ferguson, T.; Millhorn, D.E. Cobalt Inhibits the Interaction between Hypoxia-inducible Factor- $\alpha$ and von Hippel-Lindau Protein by Direct Binding to Hypoxia-inducible Factor- $\alpha$. J. Biol. Chem. 2003, 278, 15911-15916. [CrossRef]

18. Gasco, M.R.; Morel, S.; Manzoni, R. Incorporation of doxorubicine in nanoparticles obtained by polymerization from non aqueous micromulsion. Farmaco Prat 1988, 43, 373-380.

19. Nyga, A.; Hart, A.; Tetley, T.D. Molecular analysis of HIF activation as a potential biomarker for adverse reaction to metal debris (ARMD) in tissue and blood samples. J. Biomed. Mater. Res. Part B: Appl. Biomater. 2018, 107, 1352-1362. [CrossRef]

20. Savarino, L.; Fotia, C.; Roncuzzi, L.; Greco, M.; Cadossi, M.; Baldini, N.; Giannini, S. Does chronic raise of metal ion levels induce oxidative DNA damage and hypoxia-like response in patients with metal-on-metal hip resurfacing? J. Biomed. Mater. Res. Part B: Appl. Biomater. 2015, 105, 460-466. [CrossRef]

21. Shah, K.M.; Quinn, P.D.; Gartland, A.; Wilkinson, J.M. Understanding the tissue effects of tribo-corrosion: Uptake, distribution, and speciation of cobalt and chromium in human bone cells. J. Orthop. Res. 2015, 33, 114-121. [CrossRef]

22. Minchenko, A.; Leshchinsky, I.; Opentanova, I.; Sang, N.; Srinivas, V.; Armstead, V.; Caro, J. Hypoxia-inducible Factor-1-mediated Expression of the 6-Phosphofructo-2-kinase/fructose-2,6-bisphosphatase-3 (PFKFB3) Genegene: Its possible role in the Warburg effect. J. Biol. Chem. 2002, 277, 6183-6187. [CrossRef] [PubMed]

23. Leiherer, A.; Geiger, K.; Muendlein, A.; Drexel, H. Hypoxia induces a HIF-1 $\alpha$ dependent signaling cascade to make a complex metabolic switch in SGBS-adipocytes. Mol. Cell. Endocrinol. 2014, 383, 21-31. [CrossRef] [PubMed]

24. Utting, J.; Robins, S.; Brandao-Burch, A.; Orriss, I.; Behar, J.; Arnett, T. Hypoxia inhibits the growth, differentiation and bone-forming capacity of rat osteoblasts. Exp. Cell Res. 2006, 312, 1693-1702. [CrossRef] [PubMed]

25. Regan, J.N.; Lim, J.; Shi, Y.; Joeng, K.S.; Arbeit, J.M.; Shohet, R.V.; Long, F. Up-regulation of glycolytic metabolism is required for HIF1-driven bone formation. Proc. Natl. Acad. Sci. USA 2014, 111, 8673-8678. [CrossRef]

26. Stegen, S.; Laperre, K.; Eelen, G.; Rinaldi, G.; Fraisl, P.; Torrekens, S.; Van Looveren, R.; Loopmans, S.; Bultynck, G.; Vinckier, S.; et al. HIF- $1 \alpha$ metabolically controls collagen synthesis and modification in chondrocytes. Nat. Cell Biol. 2019, 565, 511-515. [CrossRef]

27. Pandit, H.; Glyn-Jones, S.; McLardy-Smith, P.; Gundle, R.; Whitwell, D.; Gibbons, C.L.M.; Ostlere, S.; Athanasou, N.; Gill, H.; Murray, D.W. Pseudotumours associated with metal-on-metal hip resurfacings. J. Bone Jt. Surg. Br. Vol. 2008, 90, 847-851. [CrossRef]

28. Paukkeri, E.-L.; Korhonen, R.; Hämäläinen, M.; Pesu, M.; Eskelinen, A.; Moilanen, T.; Moilanen, E. The Inflammatory Phenotype in Failed Metal-On-Metal Hip Arthroplasty Correlates with Blood Metal Concentrations. PLoS ONE 2016, 11, e0155121. [CrossRef] 
29. Jost-Albrecht, K.; Hofstetter, W. Gene expression by human monocytes from peripheral blood in response to exposure to metals. J. Biomed. Mater. Res. Part B 2006, 76, 449-455. [CrossRef]

30. Shin, N.-Y.; Choi, H.; Neff, L.; Wu, Y.; Saito, H.; Ferguson, S.M.; De Camilli, P.; Baron, R. Dynamin and endocytosis are required for the fusion of osteoclasts and myoblasts. J. Cell Biol. 2014, 207, 73-89. [CrossRef]

31. Stenbeck, G.; Horton, M.A. Endocytic trafficking in actively resorbing osteoclasts. J. Cell Sci. 2004, 117, 827-836. [CrossRef] [PubMed]

32. Moon, J.B.; Kim, J.H.; Kim, K.; Youn, B.U.; Ko, A.; Lee, S.Y.; Kim, N. Akt induces osteoclast differentiation through regulating the GSK3beta/NFATc1 signaling cascade. J. Immunol. 2012, 188, 163-169. [CrossRef] [PubMed]

33. Zhao, H. Membrane Trafficking in Osteoblasts and Osteoclasts: New Avenues for Understanding and Treating Skeletal Diseases. Traffic 2012, 13, 1307-1314. [CrossRef] [PubMed]

34. Zou, W.; DeSelm, C.J.; Broekelmann, T.J.; Mecham, R.P.; Pol, S.V.; Choi, K.; Teitelbaum, S.L. Paxillin contracts the osteoclast cytoskeleton. J. Bone Miner. Res. 2012, 27, 2490-2500. [CrossRef] [PubMed]

35. Rawadi, G.; Vayssière, B.; Dunn, F.; Baron, R.; Roman-Roman, S. BMP-2 Controls Alkaline Phosphatase Expression and Osteoblast Mineralization by a Wnt Autocrine Loop. J. Bone Miner. Res. 2003, 18, 1842-1853. [CrossRef]

36. Nahar-Gohad, P.; Gohad, N.; Tsai, C.-C.; Bordia, R.; Vyavahare, N. Rat aortic smooth muscle cells cultured on hydroxyapatite differentiate into osteoblast-like cells via BMP-2-SMAD-5 pathway. Calcif. Tissue Int. 2015, 96, 359-369. [CrossRef]

37. Suto, M.; Nemoto, E.; Kanaya, S.; Suzuki, R.; Tsuchiya, M.; Shimauchi, H. Nanohydroxyapatite increases BMP-2 expression via a p38 MAP kinase dependent pathway in periodontal ligament cells. Arch. Oral Biol. 2013, 58, 1021-1028. [CrossRef]

38. 16th Annual Report; National Joint Registry for England and Wales: London, UK, 2019.

39. Brakspear, K.S.; Mason, D.J. Glutamate signaling in bone. Front. Endocrinol. 2012, 3, 97. [CrossRef]

40. Keable, R.; Leshchyns'Ka, I.; Sytnyk, V. Trafficking and Activity of Glutamate and GABA Receptors: Regulation by Cell Adhesion Molecules. Neuroscientist 2020, 26, 415-437. [CrossRef]

41. Steinberg, J.; Southam, L.; Roumeliotis, T.I.; Clark, M.J.; Jayasuriya, R.L.; Swift, D.; Shah, K.M.; Butterfield, N.C.; Brooks, R.A.; McCaskie, A.W.; et al. A molecular quantitative trait locus map for osteoarthritis. Nat. Commun. 2021, 12, 1-11. [CrossRef]

42. Han, Q.; Liu, F. Low doses of Co nanoparticles induce death and regulate osteogenic differentiation in MG-63 cells. Mol. Med. Rep. 2017, 16, 7591-7596. [CrossRef] [PubMed]

43. Langton, D.J.; Sprowson, A.P.; Joyce, T.J.; Reed, M.; Carluke, I.; Partington, P.; Nargol, A.V. Blood metal ion concentrations after hip resurfacing arthroplasty: A comparative study of articular surface replacement and Birmingham Hip Resurfacing arthroplasties. J. Bone Jt. Surg. 2009, 91, 1287-1295. [CrossRef]

44. Williams, D.H.; Greidanus, N.V.; Masri, B.; Duncan, C.P.; Garbuz, D.S. Prevalence of Pseudotumor in Asymptomatic Patients After Metal-on-Metal Hip Arthroplasty. J. Bone Jt. Surg. 2011, 93, 2164-2171. [CrossRef] [PubMed]

45. Kwon, Y.M.; Ostlere, S.J.; McLardy-Smith, P.; Athanasou, N.A.; Gill, H.S.; Murray, D.W. "Asymptomatic" pseudotumors after metal-on-metal hip resurfacing arthroplasty: Prevalence and metal ion study. J. Arthroplast. 2011, 26, 511-518. [CrossRef] [PubMed]

46. Agrawal, A.; Gallagher, J.A.; Gartland, A. Human osteoclast culture and phenotypic characterization. Methods Mol. Biol. 2012, 806, 357-375.

47. Ritchie, M.E.; Phipson, B.; Wu, D.; Hu, Y.; Law, C.W.; Shi, W.; Smyth, G.K. limma powers differential expression analyses for RNA-sequencing and microarray studies. Nucleic Acids Res. 2015, 43, e47. [CrossRef]

48. Bourgon, R.; Gentleman, R.; Huber, W. Independent filtering increases detection power for high-throughput experiments. Proc. Natl. Acad. Sci. USA 2010, 107, 9546-9551. [CrossRef]

49. Huang, D.W.; Sherman, B.T.; Lempicki, R.A. Systematic and integrative analysis of large gene lists using DAVID bioinformatics resources. Nat. Protoc. 2009, 4, 44-57. [CrossRef]

50. Huang, D.W.; Sherman, B.T.; Lempicki, R.A. Bioinformatics enrichment tools: Paths toward the comprehensive functional analysis of large gene lists. Nucleic Acids Res. 2009, 37, 1-13. [CrossRef]

51. Conesa, A.; Nueda, M.J.; Ferrer, A.; Talón, M. maSigPro: A method to identify significantly differential expression profiles in time-course microarray experiments. Bioinformatics 2006, 22, 1096-1102. [CrossRef] 